\title{
Thermal Tempering Does Not Impact Rainbow Trout and Brown Trout Survival
}

\author{
Nathan Huysman, Jill M. Voorhees, Eric Krebs, Michael E. Barnes* \\ South Dakota Department of Game, Fish and Parks, McNenny State Fish Hatchery, Spearfish, SD, USA \\ Email: *mike.barnes@state.sd.us
}

How to cite this paper: Huysman, N., Voorhees, J.M., Krebs, E. and Barnes, M.E. (2020) Thermal Tempering Does Not Impact Rainbow Trout and Brown Trout Survival. Advances in Bioscience and Biotechnology, 11, 345-353.

https://doi.org/10.4236/abb.2020.117024

Received: June 7, 2020

Accepted: July 25, 2020

Published: July 28, 2020

Copyright (c) 2020 by author(s) and Scientific Research Publishing Inc. This work is licensed under the Creative Commons Attribution International License (CC BY 4.0).

http://creativecommons.org/licenses/by/4.0/

\begin{abstract}
Hatchery-reared fish are frequently adjusted (tempered) to the higher water temperatures present in the water bodies where they are to be stocked. This study was undertaken to determine the necessity of such tempering practices. This study used rainbow trout (Oncorhynchus mykiss) and brown trout (Salmo trutta) reared at $11.2^{\circ} \mathrm{C}$. The first two trials for each species were designed to simultaneously determine the upper incipient lethal temperature and $100 \%$ lethal temperature over a 14-day period. The third trial for each species evaluated the effects of an exaggerated 12-hour tempering regime on fish survival after placement in elevated water temperatures. After transfer from a water temperature of $11.2^{\circ} \mathrm{C}$, no rainbow trout survived at $26^{\circ} \mathrm{C}$, and only $50 \%$ survived at $25^{\circ} \mathrm{C}$. No brown trout survived at $22^{\circ} \mathrm{C}$ and only $50 \%$ at $20^{\circ} \mathrm{C}$. Survival of rainbow trout was not improved by the 12 -hour tempering regime where water temperatures were slowly increased from $11.2^{\circ} \mathrm{C}$ to either $25^{\circ} \mathrm{C}$ or $26^{\circ} \mathrm{C}$. Similarly, tempering did not improve brown trout survival at either $20^{\circ} \mathrm{C}$ or $22^{\circ} \mathrm{C}$. These results suggest that tempering is not needed when hatchery-reared trout are reared and stocked at the water temperatures within the range of those used in this study.
\end{abstract}

\section{Keywords}

Tempering, Rainbow Trout, Oncorhynchus mykiss, Brown Trout, Salmo trutta, Temperature

\section{Introduction}

When trout or other salmonids are transferred from cooler to warmer water, slowly tempering (adjusting) the fish to the warmer water has a long history and has been traditionally practiced by fish culturists [1-3]. This tempering process 
was particularly pervasive during the stocking of hatchery-reared trout into lakes and streams until recently when the risks of disease or invasive species transmission by using thermal tempering techniques were more fully recognized [3].

Few studies have examined tempering salmonids for thermal changes. In one of the earliest experiments, Brett [4] found that very short-term (15-min) tempering had no effect on trout survival when stocked into waters at or near lethal temperatures. Smith and Hubert [3] reported no difference in the survival of rainbow trout (Oncorhynchus mykiss) transferred from $8^{\circ} \mathrm{C}$ to $24^{\circ} \mathrm{C}$ with or without tempering. Salmonids in general can handle a $10^{\circ} \mathrm{C}$ temperature change without any issues [5]. Studies involving other fish species have also found no benefits from thermal tempering of fingerling or larger fish [6, 7]. Despite these publications, thermal tempering is still widely used and recommended $[1,8,9$, $10,11]$.

The South Dakota Department of Game, Fish and Parks has two publiclyowned trout and salmon hatcheries that stock 77 different water bodies within the state of South Dakota (USA) for recreational fishing [12]. With stockings occurring every month of the year, it is inevitable that hatchery fish reared at $11^{\circ} \mathrm{C}$ will be placed into higher temperature waters. The possible effects on the fish of stocking into such temperature gradients are unknown but given its stewardship obligations as a government agency [13], it is essential that the Department maximize the post-stocking survival of the fish. Minimizing the spread of fish pathogens and aquatic invasive species is also important [13], with increased risks associated with the use of tempering techniques such as exchanging waters between the transfer tanks and water body to be stocked [3]. Thus, the objectives of this study were two-fold, first to determine the upper thermal tolerance for the predominant trout currently stocked, and secondly to determine if thermal tempering is beneficial or needed.

\section{Methods}

\subsection{Methods Common to Each Experiment}

Six separate trials were conducted at McNenny State Fish Hatchery, Spearfish, South Dakota, USA to determine the survival of Arlee strain rainbow trout (three trials) and Saratoga strain brown trout (Salmo trutta) (three trials) at elevated temperatures with and without thermal tempering (Table 1). The first two trials determined the Upper Incipient Lethal Temperature (defined as the upper temperature where $50 \%$ of the population could theoretically survive) $[14,15]$ and the Upper Lethal Temperature (defined as the upper temperature where $100 \%$ of the fish die). The third trial used the results from the first two trials to determine the effect of an exaggerated simulated thermal tempering on both the Upper Incipient Lethal Temperature and the Upper Lethal Temperature.

Twelve 190-L semi-square tanks were used for each trial. Each tank was outfitted with a submersible recirculating pump (Pondmaster, Kissimmee, Florida, USA) attached to a spray bar that maintained dissolved oxygen levels at or near 
Table 1. Mean $( \pm$ SE) total length and weight of rainbow and brown trout for six temperature-related trials.

\begin{tabular}{cccc}
\hline Species & Trial & Length $(\mathrm{mm})$ & Weight $(\mathrm{g})$ \\
\hline Rainbow trout & 1 & $155 \pm 3$ & $36.2 \pm 2.5$ \\
& 2 & $172 \pm 3$ & $51.5 \pm 3.4$ \\
Brown trout & 3 & $175 \pm 6$ & $56.7 \pm 5.0$ \\
& 1 & $183 \pm 3$ & $77.2 \pm 5.6$ \\
& 2 & $174 \pm 4$ & $61.4 \pm 5.0$ \\
& 3 & $186 \pm 8$ & $79.0 \pm 5.4$ \\
\hline
\end{tabular}

saturation. A submersible heater (Hydor, Bassano del Grappa, Italy) with temperature controller (Finnex, Chicago, Illinois, USA) was used to maintain tank temperatures $\left( \pm 1^{\circ} \mathrm{C}\right)$ over the course of each trial. Prior to the start of each trial, tanks were cleaned and filled with well water $\left(11.2^{\circ} \mathrm{C}\right.$; total hardness $360 \mathrm{mg} / \mathrm{L}$ $\mathrm{CaCo}_{3}$; alkalinity as $\mathrm{CaCO}_{3} 210 \mathrm{mg} / \mathrm{L} ; \mathrm{pH}$ 8.3; total dissolved solids $390 \mathrm{mg} / \mathrm{L}$ ) and allowed to temperature stabilize to the experimental temperatures.

Tanks were monitored daily for total ammonia levels using a water total ammonia test kit (LaMotte, Chestertown, Maryland, USA). Ammonia levels were maintained at levels $<0.50 \mathrm{mg} / \mathrm{L}$ (free ammonia) with the addition of AmQuel Plus Ammonia Detoxifier (Kordon, Hayward, California; USA). Each tank was stocked with one fish netted from a common tank receiving the same well water that was used in the experiments. Fish were not fed the day before the trial or over the course of each 14-day trial. The trial duration was selected because $70 \%$ of the trout stocked in South Dakota are assumed to be caught within 14 days post-stocking [16]. Fish were weighed (g) and measured (total length, mm) either at the end of the trial or when mortality occurred.

Following the experiments, a chi-square analysis (SPSS 24.0; IBM, Armonk, New York, USA) was performed on each separate experiment to determine if there were any differences in survival between treatments. In addition, a oneway Analysis of Variance (ANOVA) was conducted on the time of mortality for each trial, with all fish assumed to have died by the end of the trial (day 14). Tukey's means comparison procedure was performed if the ANOVA indicated significant differences. Significance was pre-determined at $\mathrm{p}<0.05$.

\subsection{Rainbow Trout}

The first rainbow trout trial used three different temperatures $(\mathrm{n}=4): 19^{\circ} \mathrm{C}$, $22^{\circ} \mathrm{C}$, and $25^{\circ} \mathrm{C}$. The trout were directly placed in each tank from the common pool tank containing $11.2^{\circ} \mathrm{C}$ water. The upper temperature of $25^{\circ} \mathrm{C}$ was selected based on the assumption that it was the Upper Lethal Temperature for rainbow trout $[14,17,18]$, and the other temperatures have been observed in South Dakota trout stocking waters. Based on the results from Trial 1, temperatures of $18^{\circ} \mathrm{C}, 22^{\circ} \mathrm{C}$, and $26^{\circ} \mathrm{C}$ were used in Trial 2 . The second trial was identical to the first, except for the difference in some of the temperatures used. 
The third trial used an exaggerated tempering protocol. All of the tanks used in this trial initially contained $11.2^{\circ} \mathrm{C}$ water. After the rainbow trout were transferred from the common pool, also at $11.2^{\circ} \mathrm{C}$, the tank heaters were engaged, and water temperatures in the tanks slowly began to increase to three predetermined temperatures: $16^{\circ} \mathrm{C}, 25^{\circ} \mathrm{C}$, and $26^{\circ} \mathrm{C}$. Four tanks were used for each temperature $(n=4)$. The overall tempering times and thermal rate of increase for each temperature treatment were: $16^{\circ} \mathrm{C}-12^{\circ} \mathrm{C}$ hours $\left(0.41^{\circ} \mathrm{C} /\right.$ hour $) ; 25^{\circ} \mathrm{C}-11$ hours $\left(1.27^{\circ} \mathrm{C} /\right.$ hour $)$; and $26^{\circ} \mathrm{C}-12$ hours $\left(1.25^{\circ} \mathrm{C} /\right.$ hour $)$.

\subsection{Brown Trout}

The experimental designs used for all three brown trout trials were similar to those described previously for rainbow trout. The first trial used temperatures of $13^{\circ} \mathrm{C}, 22^{\circ} \mathrm{C}$, and $25^{\circ} \mathrm{C}$, and the brown trout were originally held in $11.2^{\circ} \mathrm{C}$ water. The Upper Lethal Temperature for brown trout has been reported from $22^{\circ} \mathrm{C}$ to $25^{\circ} \mathrm{C}[14,17,19]$. Based on the results from Trial 1 , temperatures of $13^{\circ} \mathrm{C}, 20^{\circ} \mathrm{C}$ and $22^{\circ} \mathrm{C}$ were used in the second trial. In the third trial, brown trout were directly placed into their respective tanks containing $11.2^{\circ} \mathrm{C}$ water and slowly tempered to $13^{\circ} \mathrm{C}, 20^{\circ} \mathrm{C}$ and $22^{\circ} \mathrm{C}$. The overall tempering times and thermal rate of increase for each temperature treatment were: $13^{\circ} \mathrm{C}-9$ hours $\left(0.22^{\circ} \mathrm{C} /\right.$ hour $)$; $20^{\circ} \mathrm{C}-9$ hours $\left(1.00^{\circ} \mathrm{C} /\right.$ hour $)$; and $22^{\circ} \mathrm{C}-10$ hours $\left(1.10^{\circ} \mathrm{C} /\right.$ hour $)$.

\section{Results}

\subsection{Rainbow Trout}

In trial 1, all of the fish in the $19^{\circ} \mathrm{C}$ tanks survived, compared to $75 \%$ and $50 \%$ of the trout in the $22^{\circ} \mathrm{C}$ and $25^{\circ} \mathrm{C}$ tanks (Table 2). However, there was no significant difference among these means $(x=2.67, p=0.26)$. All mortality occurred

Table 2. Mean number of days $( \pm \mathrm{SE})$ and percent survival (\%) of rainbow trout from three separate 14-day trials involving placement of fish into tanks at different water temperatures without tempering (Trial 1 and 2) and with an exaggerated tempering routine (Trial 3). Means for each trial in a column followed by different superscript letters are significantly different $(p=0.05)$.

\begin{tabular}{cccc}
\hline Trial & Temp $\left({ }^{\circ} \mathrm{C}\right)$ & Days Alive & Survival (\%) \\
\hline \multirow{3}{*}{ 1-Untempered } & 19 & $14.0 \pm 0.0$ & 100 \\
& 22 & $13.0 \pm 1.0$ & 75 \\
& 25 & $10.8 \pm 1.9$ & 50 \\
2-Untempered & 18 & $14.0 \pm 0.0^{\mathrm{z}}$ & $100^{\mathrm{z}}$ \\
& 22 & $14.0 \pm 0.0^{\mathrm{z}}$ & $100^{\mathrm{z}}$ \\
& 26 & $0.75 \pm 0.3^{\mathrm{y}}$ & $0^{\mathrm{y}}$ \\
& 16 & $14.0 \pm 0.0^{\mathrm{z}}$ & $100^{\mathrm{z}}$ \\
3-Tempered & 25 & $10.3 \pm 1.9^{\mathrm{z}}$ & $25^{\mathrm{y}}$ \\
& 26 & $5.3 \pm 0.9^{\mathrm{y}}$ & $0^{\mathrm{y}}$ \\
\hline
\end{tabular}


between seven and ten days after the start of the experiment. In the second trial, all fish survived in the $18^{\circ} \mathrm{C}$ and $22^{\circ} \mathrm{C}$ tanks, which was significantly different than the $100 \%$ mortality observed in the $26^{\circ} \mathrm{C}$ tanks $(x=12.0, p=0.002)$. The mortality at $26^{\circ} \mathrm{C}$ occurred within 24 hours after placement of the trout in the tanks. Thus, $25^{\circ} \mathrm{C}$ was the rainbow trout Upper Incipient Lethal Temperature and $26^{\circ} \mathrm{C}$ was the Upper Lethal Temperature. Mean survival was significantly different $(x=8.91, p=0.01)$ among the tempering treatments in third trial, with $100 \%$ survival at $16^{\circ} \mathrm{C}, 50 \%$ at $25^{\circ} \mathrm{C}$, and $0 \%$ at $26^{\circ} \mathrm{C}$. These results were consistent with the other two trials. Compared to the rapid mortality at $26^{\circ} \mathrm{C}$ in Trial 2 however, the timing of mortality was delayed by several days in the $26^{\circ} \mathrm{C}$ trout that were tempered in Trial 3.

\subsection{Brown Trout}

Brown trout survival was significantly different $(x=8.90, p=0.01)$ among the treatments in the first trial, with $100 \%$ survival at $13^{\circ} \mathrm{C}, 25 \%$ at $22^{\circ} \mathrm{C}$, and $0 \%$ at $25^{\circ} \mathrm{C}$ (Table 3 ). All the brown trout placed into $25^{\circ} \mathrm{C}$ water died within the first day. Results were similar in the second trial, with significantly greater survival at $13^{\circ} \mathrm{C}(100 \%)$, compared to $50 \%$ at $20^{\circ} \mathrm{C}$, and $0 \%$ at $22^{\circ} \mathrm{C}(x=8.0, p=0.02)$, with most of the mortality occurring within the first week of the trial. Thus $20^{\circ} \mathrm{C}$ was the brown trout Upper Incipient Lethal Temperature and $22^{\circ} \mathrm{C}$ the Upper Lethal Temperature. Thermal tempering in the third trial did not change brown trout survival, with the results similar to the second trial. Survival was significantly greater at $13^{\circ} \mathrm{C}$ where all of the fish survived, compared to $25 \%$ at $20^{\circ} \mathrm{C}$, and $0 \%$ at $22^{\circ} \mathrm{C}(x=8.9, p=0.01)$. Tempering also did not influence the timing of mortality.

Table 3. Mean number of days ( \pm SE) and percent survival (\%) of brown trout from three separate 14-day trials involving placement of fish into tanks at different water temperatures without tempering (Trial 1 and 2) and with an exaggerated tempering routine (Trial $3)$. Means for each trial in a column followed by different superscript letters are significantly different $(p=0.05)$.

\begin{tabular}{|c|c|c|c|}
\hline Trial & Temp $\left({ }^{\circ} \mathrm{C}\right)$ & Days Alive & Survival (\%) \\
\hline \multirow{3}{*}{ 1-Untempered } & 13 & $14.0 \pm 0.0^{z}$ & $100^{z}$ \\
\hline & 22 & $7.3 \pm 2.3^{y}$ & $25^{y}$ \\
\hline & 25 & $1.0 \pm 0.0^{\mathrm{x}}$ & $0^{y}$ \\
\hline \multirow{3}{*}{ 2-Untempered } & 13 & $14.0 \pm 0.0^{z}$ & $100^{z}$ \\
\hline & 20 & $11.3 \pm 1.7^{z}$ & $50^{y}$ \\
\hline & 22 & $6.0 \pm 0.8^{y}$ & $0^{\mathrm{x}}$ \\
\hline \multirow{3}{*}{ 3-Tempered } & 13 & $14.0 \pm 0.0^{z}$ & $100^{z}$ \\
\hline & 20 & $13.8 \pm 0.3^{z}$ & $75^{z}$ \\
\hline & 22 & $7.3 \pm 0.6^{y}$ & $0^{y}$ \\
\hline
\end{tabular}




\section{Discussion}

The results of this experiment strongly suggest that adjusting trout to increased water temperatures during stocking activities is not needed. Similarly, Smith and Hubert [3] did not observe any positive effects from tempering during the stocking for juvenile rainbow trout from $8^{\circ} \mathrm{C}$ to $24^{\circ} \mathrm{C}$ water. Brett [4] also found no benefit from short term thermal tempering with brook trout (Salvelinus fontinalis). These results also support the statement that salmonids in general can handle a $10^{\circ} \mathrm{C}$ temperature change without any issues [5]. In other species, thermal tempering has also been shown to be ineffective. Mather and Wahl [6] found litthe to no effect of tempering three different esocids to near lethal water temperatures pre-stocking. In addition, Clapp et al. [7] found no benefits to tempering in juvenile percids. Although the results of this study apply to only two salmonid species at relatively large sizes, the blanket recommendations for thermal tempering proposed by Piper et al. [1], Noga [8], Timmons et al. [9], Harmon [10] and Wynne and Wurts [11] may need to be reconsidered.

Although thermal tempering may not be needed, tempering of fish in relation to water chemistry has been shown to be beneficial [20-22]. Rapidly changing water chemistry, such as hardness, $\mathrm{pH}$, and salinity, is a major stressor for fish and can even cause mortality [23]. Water chemistry was controlled for in the present study; only temperature was changed among the treatments.

Eliminating the need for thermal tempering reduces the risk of fish pathogen transmission or the spread of aquatic invasive species [3]. Traditional tempering practices involved slowly exchanging the water in the transfer (stocking) tanks with water from the lake or stream to be stocked [2], thereby allowing for the introduction of foreign organisms into the transfer tank and possibly beyond. By ceasing this water exchange, a possible contamination vector is eliminated, as well as the need for subsequent tank disinfection or anti-invasive species chemical treatments [24-26].

While the exaggerated thermal tempering regime used in this study did slightly delay mortality, the same percentage of fish died in the tempered and untempered treatments. Thus, the two-week post-tempering duration in this study provided results that may not have been observed if the study only lasted for the shorter time frames used by Smith and Hubert [3] or Clapp et al. [7]. Of course, additional mortality could have possibly occurred after the 14-day observation period of this study. While short-term experiments hold value, longer term experiments may more accurately express the potential survivability of the fish in the receiving waters. Wehrly et al. [27] suggested that a 7-day Upper Incipient Lethal Temperature may not be long enough to ascertain when $50 \%$ of a population may die, and Selong et al. [28] used a 60-day Acclimated Chronic Exposure method to determine thermal tolerance in bull trout (Salvelinus confluentus).

The Upper Incipient Lethal Temperature of $25^{\circ} \mathrm{C}$ and Upper Lethal Temperature of $26^{\circ} \mathrm{C}$ for rainbow trout observed in this study are similar to what has been previously reported. An Upper Lethal Temperature of $25^{\circ} \mathrm{C}$ was also ob- 
served by Cherry et al. [17] and Hokanson et al. [18], as reviewed by Jobling [14]. In contrast, Bidgood and Berst [29] and Alabaster and Welcomme [30] found the Upper Lethal Temperature of rainbow trout was $26^{\circ} \mathrm{C}$ and $26.5^{\circ} \mathrm{C}$ respectively. The brown trout Upper Lethal Temperature of $22^{\circ} \mathrm{C}$ in the present study is close to the $23^{\circ} \mathrm{C}$ value reported by both Bishai [19] and Cherry et al. [17].

The results from this set of experiments strongly suggest that as long as water chemistry is similar between hatchery water and waters to be stocked, using an exaggerated tempering regime to adjust trout to elevated temperatures will not positively affect survival. Future studies should examine the possible interactions between changes in both temperature and water chemistry, as well as evaluate thermal tempering in other fish species.

\section{Acknowledgements}

Thanks to Lynn Slama and Michael Robidoux for their assistance with this study.

\section{Conflicts of Interest}

The authors declare no conflicts of interest regarding the publication of this paper.

\section{References}

[1] Piper, R.G., McElwain, I.B., Orme, L.E., McCraren, J.P., Fowler, L.G. and Leonard, J.R. (1982) Fish Hatchery Management. U.S. Fish and Wildlife Service, Washington DC.

[2] Hartman, K.J. and Preston, B. (2001) Stocking. In: Wedemeyer, G.A., Ed., Fish Hatchery Management, 2nd Edition, American Fisheries Society, Bethesda, 661-686.

[3] Smith, M.A. and Hubert, W.A. (2003) Simulated Thermal Tempering versus Sudden Temperature Change and Short-Term Survival of Fingerling Rainbow Trout. North American Journal of Aquaculture, 65, 67-69. https://doi.org/10.1577/1548-8454(2003)065<0067:STTVST>2.0.CO;2

[4] Brett, J.R. (1941) Tempering versus Acclimation in the Planting of Speckled Trout. Transactions of the American Fisheries Society, 70, 397-403. https://doi.org/10.1577/1548-8659(1940)70[397:TVAITP]2.0.CO;2

[5] Wedemeyer, G.A. (1996) Physiology of Intensive Culture Systems. Chapman and Hall, New York. https://doi.org/10.1007/978-1-4615-6011-1

[6] Mather, M.E. and Wahl, D.H. (1989) Comparative Mortality of Three Escoids Due to Stocking Stressors. Canadian Journal of Fisheries and Aquatic Sciences, 46, 214 217. https://doi.org/10.1139/f89-029

[7] Clapp, D.F., Bhagwat, Y. and Wahl, D.H. (1997) The Effect of Thermal Stress on Walleye Fry and Fingerling Mortality. North American Journal of Fisheries Management, 17, 429-437. https://doi.org/10.1577/1548-8675(1997)017<0429:TEOTSO >2.3.CO;2

[8] Noga, E.J. (2000) Fish Disease: Diagnosis and Treatment. Iowa State University Press, Ames.

[9] Timmons, E.B., Ebeling, J.M., Wheaton, F.W., Summerfelt, S.T. and Cayuga, B.J. (2002) Recirculating Aquaculture Systems. No. SH137. R37. Cayuga Aqua Adven- 
tures, Ithaca.

[10] Harmon, T.S. (2009) Methods for Reducing Stressors and Maintaining Water Quality Associated with Live Fish Transport in Tanks: A Review of the Basics. Reviews in Aquaculture, 1, 58-66. https://doi.org/10.1111/j.1753-5131.2008.01003.x

[11] Wynne, F. and Wurts, W.A. (2011) Transportation of Warmwater Fish: Equipment and Guidelines. Southern Regional Aquaculture Center, Stoneville.

[12] SDGFP (South Dakota Department of Game, Fish and Parks) (2019) 2019 Annual Technical Fish Stocking Report. Pierre. https://apps.sd.gov/GF56FisheriesReports

[13] SDGFP (South Dakota Department of Game, Fish and Parks) (2015) Strategic Plan 2016-2020. Pierre. https://gfp.sd.gov/userdocs/docs/strategic-plan-2.pdf

[14] Jobling, M. (1981) Temperature Tolerance and the Final Preferendum-Rapid Methods for the Assessment of Optimum Growth Temperatures. Journal of Fish Biology, 19, 439-455. https://doi.org/10.1111/j.1095-8649.1981.tb05847.x

[15] Kilgour, D.M. and McCauley, R.W. (1986) Reconciling the Two Methods of Measuring Upper Lethal Temperatures in Fishes. Environmental Biology of Fishes, 17, 281-290. https://doi.org/10.1007/BF00001494

[16] Kientz, J.L., Barnes, M.E. and Durben, D.J. (2017) Concentration of Stocked Rainbow Trout Catch and Harvest by a Small Number of Recreational Anglers. Journal of Fisheries Sciences.com, 11, 67-76. https://doi.org/10.21767/1307-234X.1000111

[17] Cherry, D.S., Dickson, K.L., Cairns Jr., J. and Stauffer, J.R. (1977) Preferred, Avoided and Lethal Temperatures of Fish During Rising Temperature Conditions. Journal of the Fisheries Research Board of Canada, 34, 239-246. https://doi.org/10.1139/f77-035

[18] Hokanson, K.E.F. (1977) Temperature Requirements of Some Percids and Adaptations to the Seasonal Temperature Cycle. Journal of the Fisheries Research Board of Canada, 34, 1524-1550. https://doi.org/10.1139/f77-217

[19] Bishai, H.M. (1960) Upper Lethal Temperature for Larval Salmonids. ICES Journal of Marine Sciences, 25, 129-133. https://doi.org/10.1093/icesjms/25.2.129

[20] Wagner, E.J., Bosakowski, T. and Interlmann, S. (1997) Combined Effects of Temperature and High $\mathrm{pH}$ on Mortality and the Stress Response of Rainbow Trout after Stocking. Transactions of the American Fisheries Society, 126, 985-998. https://doi.org/10.1577/1548-8659(1997)126<0985:CEOTAH >2.3.CO;2

[21] Walker, H.D., Coates, G.I. and Wilhelm, S. (2000) Impacts of Increased Tempering Lengths on Twenty-Four-Hour Survival of Hybrid Striped Bass Fry. North American Journal of Aquaculture, 62, 316-318. https://doi.org/10.1577/1548-8454(2000)062<0316:IOITLO >2.0.CO;2

[22] Trushenski, J.T., Larsen, D.A., Middleton, M.A., Jakaitis, M., Johnson, E.L., Kozfkay, C.C. and Kline, P.A. (2019) Search for the Smoking Gun: Identifying and Addressing the Causes of Postrelease Morbidity and Mortality of Hatchery-Reared Snake River Sockeye Salmon Smolts. Transactions of the American Fisheries Society, 148, 875-895. https://doi.org/10.1002/tafs.10193

[23] Barton, B.A. (2002) Stress in Fishes: A Diversity of Responses with Particular Reference to Changes in Circulating Corticosteroids. Society for Integrative and Comparative Biology, 42, 517-525. https://doi.org/10.1093/icb/42.3.517

[24] Hnath, J.G. (1983) Hatchery Disinfection and Disposal of Infected Stocks. In: Meyer, F.P., Warren, J.W. and Carey, T.G., Eds., A Guide to Integrated Fish Health Management in the Great Lakes Basin, Wildlife Disease Association, Lawrence, 121134.

[25] Edwards, W.J., Babcock-Johnson, L. and Culver, D.A. (2002) Field Testing of Pro- 
tocols to Prevent the Spread of Zebra Mussels (Dreissena polymorpha) during Fish Hatchery and Aquaculture Activities. North American Journal of Aquaculture, 64, 220-223. https://doi.org/10.1577/1548-8454(2002)064<0220:FTOPTP >2.0.CO;2

[26] Pucherelli, S.F., Portz, D.E., Bloom, K., Carmon, J., Brenimer, S. and Hosler, D. (2014) Quagga Mussel Contamination of Fish Haul Trucks by Fish and Development of Effective Potassium Chloride and Formalin Treatments. Journal of Applied Aquaculture, 26, 132-148. https://doi.org/10.1080/10454438.2013.873756

[27] Wehrly, K.E., Wang, L. and Mitro, M. (2007) Field-Based Estimates of Thermal Tolerance Limits for Trout: Incorporating Exposure Time and Temperature Fluctuation. Transactions of the American Fisheries Society, 136, 365-374. https://doi.org/10.1577/T06-163.1

[28] Selong, J.H., McMahon, T.E., Zale, A.V. and Barrows, F.T. (2001) Effect of Temperature on Growth and Survival of Bull Trout, with Application of an Improved Method for Determining Thermal Tolerances in Fishes. Transactions of the American Fisheries Society, 130, 1026-1037. https://doi.org/10.1577/1548-8659(2001)130<1026:EOTOGA $>2.0 . C O ; 2$

[29] Bidgood, B.F. and Berst, A.H. (1969) Lethal Temperatures for Great Lakes Rainbow Trout. Journal of the Fisheries Research Board of Canada, 26, 456-459. https://doi.org/10.1139/f69-044

[30] Alabaster, J.S. and Welcomme, R.L. (1962) Effect of Dissolved Oxygen on Survival of Trout and Roach in Lethal Temperatures. Nature, 194, 107. https://doi.org/10.1038/194107a0 